\title{
Marek Oziewicz
}

\section{Joseph Campbell's "New Mythology" and the Rise of Mythopoeic Fantasy}

\begin{abstract}
If the twentieth century witnessed a "rehabilitation of myth" in literary studies, the upsurge of interest in mythic systems with their ideologies, worldviews, and functional modes is rightly attributed to the work of C. G. Jung, Mircea Eliade, Northrop Frye, and Joseph Campbell. Behind their thousand faces, those thinkers argued, myths carry one message, which reflects the psychic unity of humankind. And because we are becoming more conscious of this unity, we face the need to "tell ourselves" anew and imagine a new mythology apposite to the modern situation. In The Inner Reaches of Outer Space, Joseph Campbell presents this new mythology as one of the whole human race; saying it is relevant to our present knowledge, already implicit among humans as intuitive knowledge, and will be realized in and through art. These postulates are met in and chronologically overlap with the emergence of modern mythopoeic fantasy in Tolkien, Lewis, L'Engle, Le Guin, Alexander, and others. This paper suggests that works of mythopoeic fantasy can be seen as exploring the components of the new story of unifying the human race and play an important role in shaping modern readers' response to contemporary challenges of an increasingly shrinking world.
\end{abstract}

\section{Introduction}

The late 1940s saw the publication of several important works which can be seen as thread-ends of the two strands - rehabilitation of myth and the rise of mythopoeic fantasy - I want to weave together in this paper. As early as in 1941, Carl G. Jung and Carl Kerényi's Essays on a Science of Mythology argued for mythology as "the rearising of a primordial reality in narrative form" and a type of narrative whose "meaning is so hard to translate into the language of science because it can be fully

The AnaChronisT 13 (2007-2008): 114-130 ISSN 1219-2589 
expressed only in mythological terms." In 1947, two years before Jung and Kerényi's work was made available to an English audience, a collection Essays Presented to Charles Williams brought out for the first time two articles which became seminal for the development of mythopoeic fantasy: Lewis's "On Stories," and Tolkien's "On Fairy-Stories." In these groundbreaking essays Lewis and Tolkien argued for a new genre, a new type of mythopoeic literary formula most conducive, in the present circumstances, for expressing important things about the human condition. That same year, on the other side of the Atlantic, a young Canadian critic published Fearful Symmetry: A Study of William Blake which demonstrated how important a rich mythopoeic structure was for Blake's total vision and for our understanding of his work. And if with this first major book Northrop Frye embarked on his own literarycritical crusade aimed at re-evaluating the place of myth in our culture, he was not meant to be alone. In 1949 he was joined by two other champions of the revival of myth who would become prolific and influential writers on the subject. These were Joseph Campbell, whose The Hero with a Thousand Faces posited that mythologies are creative manifestations of the human need to be intimately in touch with our universal psychological and spiritual realities; and Mircea Eliade, whose The Myth of the Eternal Return, or Cosmos and History substantiated that myth is an ontological, value-conferring narrative which allows humans to participate in a transcendent, perennial existence.

This was just the beginning, for the remaining decades of the twentieth century saw an unprecedented amount of research into myth and its survival in our culture. While the scope of this essay precludes even a general exposition of this huge project, I propose to link the modern renewal of interest in myth with the rise of the genre of mythopoeic fantasy. In this context I shall argue that Campbell's postulates about the Western civilization facing the need to "tell itself" anew - to come up with a new mythology apposite to the modern situation - are being realized in mythopoeic fantasy.

\section{Twentieth-Century Rehabilitation of Myth}

The colloquial functioning of the word "myth" in our culture - meaning a story or its underlying belief which is false, manipulative and superstitious - suggests the extent of mauling that the term underwent since the Enlightenment. In the pre-modern

1. Carl G. Jung and Carl Kerényi, Essays on a Science of Mythology (Princeton N.J.: Princeton UP, 1993), pp. 6; 3-4. 
times, as Karen Armstrong shows in her 2001 The Battle for God, it was believed that there are two modes of thinking, arguing, speaking, and acquiring knowledge called, in shorthand terms, mythos and logos. "Both were essential," says Armstrong, "and each had its special area of competence." While myth was regarded as primary since it was concerned with the origins of life, with the foundations of culture, and invested human existence with meaning, "logos was the rational, pragmatic, scientific thought that enabled men and women to function well in the world." $3 \mathrm{Al}-$ though they had separate jobs to do, "both mythos and logos were regarded as indispensable" for the people of the pre-modern world continued to see them as complementary ways of arriving at truth - complementary to the extent that one would be impoverished without the other. 4 This, however, is precisely what happened in the wake of the Enlightenment enrapture with logos. Starting in the late eighteenth century, amazing success in science and technology has encouraged people to disregard mythos as something false and superstitious.

For the nineteenth-century minds myth - with its literal or symbolic "interpretations" of the world - was the primitive counterpart of science whose advent made it, in the words of Robert Segal, "not merely redundant but outright incompatible" with a modern outlook. 5 While the naturalists led by a comparative mythologist Max Müller saw myth as a disease of language which sets out when the symbolic or metaphorical referents of a story to abstract concepts are forgotten and replaced with personifications, anthropologists such as E. B. Tylor and folklorists such as Andrew Lang interpreted it as primitive science. In both perspectives, however, myth was equally false and misinforming - a reason why Eleazar Meletinsky, who meant that myth was "a pre-scientific method to understand the environment" and the human experience of it, in 1976 contended that "the contrast between the naturalists and the anthropologists is not particularly profound." 6

In this respect the most important difference between the theories of myth in the nineteenth and twentieth centuries is that the latter "have tended to see myth as almost anything but an outdated counterpart to science" and never posited that it

2. Karen Armstrong, The Battle for God: Fundamentalism in Judaism, Christianity and Islam (London: HarperCollins, 2001), p. xiii.

3. Armstrong, p. xiv.

4. Armstrong, p. xv.

5. Robert Segal, Myth: A Very Short Introduction (New York: Oxford University Press, 2004), p. 5.

6. Eleazar Meletinsky, The Poetics of Myth (New York: Routledge, 2000). 
must be abandoned for science.7 On the contrary, whether derived from anthropology, psychology, sociology, religious studies, literature, linguistics or other disciplines, these theories asserted that myth cannot be disregarded in any serious inquiry that purports to understand how we function as individuals, as a society, and as a culture. Already in 1941 Carl Kerényi asserted that we must "demand back from science ... this feeling of immediacy between ourselves and scientific subjects. Science herself must throw open the road to mythology that she blocked first with her interpretations and then with her explanations." 8 This urge must have been felt by many other scholars for soon it was followed by such proliferation of theorizing that by now, in the words of Robert Segal, "each discipline harbours multiple theories of myth.” To complicate matters, Segal explains,

theories of myth are theories of some much larger domain, with myth as a mere subset. For example anthropological theories of myth are theories of culture applied to the case of myth. Psychological theories of myth are theories of the mind. Sociological theories of myth are theories of society. There are no theories of myth itself, for there is no discipline of myth in itself. 9

If Segal is right - as I think he is - about there being no such discipline as myth in itself, one implication of this statement is that any theorizing of myth offered from within any discipline is perforce provisional. Segal's claim may also be taken to explain the mechanism behind the contemporary multiplication of theories of myth: if no discipline can claim myth as exclusively its own, it is legitimate that specialists from many fields may want to comment on it from their respective angles. The most obvious consequence of this broad process has been the twentieth-century rehabilitation of myth, evident not through the emergence of some dominant theory of myth but in the fact that in the past six or seven decades more scholars took myth seriously than ever before. While the answers they provided to the questions of its origin, function, subject matter, universality and truth value differed, the theories proposed can be roughly divided, as Segal suggests, into those that contend "that myth arises and functions to explain natural processes" and those that declare that it "arises and functions to unify society."10

7. Segal, p. 3 .

8. Jung and Kerényi, p. 2.

9. Segal, p. 3.

10. Segal, p. 4. 
Impossible and unnecessary as it is to review all those theories, the most important ones for the argument of this paper belong to the second category and have explained myths as carrying one message which reflects the psychic unity of humankind. Four theorists were especially prominent spokesmen for this approach: Mircea Eliade who discussed myths from an angle of religion studies; Carl Gustav Jung who theorized about them in the context of psychology; Northrop Frye who studied the working of myth in literature, and Joseph Campbell who explored the totality of myth's impact by referring to the insights of all three disciplines. These four, at least, are usually credited with generating the modern upsurge of interest in mythic systems with their ideologies, worldviews and functional modes in literary studies.

For Eliade, all myth is religious in a sense that it records hierophanies of everyday life, or, as he says in his 1963 Myth and Reality, it describes "the various and sometimes dramatic breakthroughs of the sacred (or the 'supernatural') into the World." "11 As a result, Eliade's

interpretations of myth consist of identifying and analyzing the deep structures and meanings, often hidden and camouflaged, of the mythic disclosures of the sacred. Even when he speaks of modern, "secular myths," these are invariably analyzed as responding to deeper religious nostalgias and desires for the sacred, as revealing hidden or repressed religious structures and meanings, as inadequate substitutes for the fully mythic sacred, or as superficial, transitory, pseudoreligious creations. ${ }^{12}$

This - just as much as Eliade's definition of myth as "the most general and effective means of awakening and maintaining consciousness of another world, a beyond, [which] represents a superhuman, 'transcendent' plane, the plane of absolute realities"13 - points to the underlying unity that Eliade posits for and behind myths. In his perspective, myths are stories which reveal that each of us is, deep in our core, a homo religiosus - archaic or religious being - whose experience of the world is meaningful inasmuch as it is tied to the sacred. Besides being powerful statements about us and our cognitive apparatus, myths also suggest an ontological reality: that of an objective, transcendent reality to which all creation is inherently bound. This is

11. Mircea Eliade, Myth and Reality (New York: Harper \& Row, 1963), p. 6.

12. Douglas Allen, Myth and Religion in Mircea Eliade (New York: Routledge, 2002), p. 185 .

13. Eliade, p. 139. 
why Eliade insists that myths are "true stories," different from fables, legends and other types of tales which have no claim to reality. ${ }^{14}$ Irreducibly religious, for Eliade myths are also irreducibly symbolic, with their "own symbolic logic, symbolic mode of cognition and so on - all aimed to disclose a meaning of human existence."15

In many ways Eliade's claims echo those of Jung whose perspective on myth from within analytical psychology involves recognition of "the existence of an authentic religious function in the unconscious mind," which operates by means of symbols and symbolic narratives. ${ }^{16}$ Strongly opposing the literal interpretation of myths, Jung saw them as stories of archetypal encounters which affect us so much because they derive from the collective unconscious - "a common psychic substrate of a suprapersonal nature which is present in every one of us." 17 Conceived as a reservoir of archetypal structures, experiences, and themes, Jung's collective unconscious is his most compelling contribution to the study of myth for a number of reasons. It suggests that "the pre-conditions for myth-formation are present within the structure of the psyche itself" and thus implies a deep psychic unity of all humankind. ${ }^{18}$ It accounts for the affective power of myth whose "archetypal situation[s]" make us "suddenly feel an extraordinary sense of release, as though [we were] transported, or caught up by an overwhelming power. At such moments we are no longer individuals, but the race; the voice of all mankind resounds in us."19 It redefines myths and mythic stories "as statements of psyche about itself"; ${ }^{20}$ statements which are not invented as rather experienced by us in that myths, as Jung says, "are original revelations of the pre-conscious psyche, involuntary statements about psychic happenings." ${ }^{21}$ It accounts for the similarities between myths of the societies remote from one another in time and place. It gives us the key, in the form of his theory of individuation, to understand the role of myths in the process of harmoniz-

\footnotetext{
14. Eliade, pp. 6-8.

15. Allen, p. 180.

16. Carl Gustav Jung, Psychology and Religion (New Haven and London: Yale UP, 1966), p. 3 .

17. Carl Gustav Jung, Archetypes and the Collective Unconscious (Princeton, N.J.: Princeton UP, 1969), p. 4.

18. Andrew Samuels, A Critical Dictionary of Jungian Analysis (London and New York: Routledge, 1986), p. 95.

19. Carl Gustav Jung, The Spirit in Man, Art, and Literature (Princeton, N.J.: Princeton UP, 1971), p. 82.

20. Jung and Kerényi, p. 74.

21. Jung and Kerényi, p. 73.
} 
ing the components of personality by means of which a person achieves, in the words of Meletinsky, "the definitive synthesis of consciousness with the unconscious, of the individual with the collective, and of the internal world with the environment." 22 Finally, it translates so well into the study of mythic structures, imagery and narrative elements in literature that it has even generated a school of criticism called archetypal criticism.

Contrary to Jung's explicit focus on the archetypes and through them on myth, Northrop Frye's centre of attention was myth and only indirectly archetypes. Thus, although in his 1957 Anatomy of Criticism Frye did employ Jungian terms and archetypal concepts, his approach should more appropriately be termed myth criticism. Besides his focus, two factors distinguish Frye's approach from the archetypal angle. One is his downplaying of Jung's theory of collective unconscious as "an unnecessary hypothesis in literary criticism" 23 combined with his redefinition of archetype as a communicable symbol or a kind of literary occurrence per se resembling a convention - by which he severs the connection between archetype and depth psychology. ${ }^{24}$ Two is his concern as a literary critic to make literary criticism more methodical so that its interpretations could be more precise - a sharp contrast with Jung who claimed that "an archetypal content" which manifests itself in symbols and metaphors of myths must "remain unknown and [can] not to be fitted into a formula." 25

With that said, Jung's and Frye's theories greatly overlap; the former used archetype and myth to illumine the working of the unconscious, the latter used them to rediscover the content of literature. Frye believed that the totality of literature is an extension and sophistication of a set of basic and universal formulas found in myths, and wrote his Anatomy in an attempt to build taxonomy of literature as a "displaced" mythology, best understood if interpreted in its correct mythical context. Although the system of literary classification he proposed never caught on, Frye has been especially influential in identifying the quest-myth as the central myth of literature and the source of all literary genres. In this, without collapsing literature into myth, he not only asserted the mythic origin of literature but also demonstrated the survival of mythic patterns even in most realistic genres - with myth being "not only the beginning but also the culmination of [his] five-mode cycle." 26

22. Meletinsky, p. 42.

23. Northrop Frye, Anatomy of Criticism (Princeton N.J.: Princeton UP, 1973), pp. 111-2.

24. Frye, p. 107.

25. Jung and Kerényi, p. 76.

26. Meletinsky, p. 85. 
If for Eliade myths point to the underlying unity behind humanity's religious experience, for Jung to unity behind our conscious minds, and for Frye to unity behind our artistic creations, especially literature, Campbell is a great synthesizer of all those positions. A literature scholar by training, a comparative mythographer by passion, and a transcendentalist - actually a "mystic" according to Segal 27 - by nature, Campbell believed that humanity lives in "the one, shape-shifting yet marvelously constant story." Called myth, it is "the secret opening through which the inexhaustible energies of the cosmos pour into human cultural manifestation," bringing forth "[r]eligions, philosophies, arts, the social forms ... discoveries in science and technology" and all other products of human civilization. ${ }^{28}$ Its social function notwithstanding, myth for Campbell also serves the psychological and mystical functions: in the former it conducts individuals through "psychophysiological stages of transformation of a human lifetime";29 in the latter it provides "a sense of actual participation in ... a realization of transcendence, infinity, and abundance" which opens a person's "mind and heart to the utter wonder of all being" and reveals the universe as an epiphany. $3^{\circ}$

Just as it was in the case of Eliade, Jung, and Frye, one of Campbell's leading assumptions was that Western civilization's neglect of mythos and unqualified idolatry of logos has brought us to the verge of collapse. In this sense, for each of those scholars, the passion with which they argued for the need to "return to myth" and grasp its crucial place in the life of an individual and of a society was informed by an acute sense of crisis - an almost life or death choice, the stake of which was individual's sanity and the survival of a civilization. If we can no longer ignore myth, they argued, let us try to understand it and attune ourselves to its universal message: that of unity of all humankind. And because we are presently becoming more conscious of this underlying unity, they said, we face the need to "tell ourselves" anew - to do what in his 1986 The Inner Reaches of Outer Space Campbell has called constructing a new mythology apposite to the modern situation.

For Campbell, who was the most ardent proponent of this idea, already in his 1968 The Masks of God: Creative Mythology it was clear that "[t]he rise and fall of civilizations in the long, broad course of history can be seen to have been largely the

27. Robert Segal, Joseph Campbell: An Introduction (New York: Penguin, 1990), p. 58.

28. Joseph Campbell, The Hero with a Thousand Faces (Princeton N. J.: Princeton UP, 1973), p. 3.

29. Joseph Campbell, The Inner Reaches of Outer Space (Novato, CA: New World Library, 2002), p. xxiii.

30. Campbell, The Inner Reaches, pp. $\mathrm{xx}-\mathrm{xxi}$. 
function of the integrity and cogency of their supporting canons of myth." Given that, as he claims, the modern West has too long rested on "beliefs no longer universally held ... but universally enforced," ${ }^{31}$ and given that no civilization can live without some myth, we are now in need of a creative mythology - "a totally new type of nontheological revelation, of great scope, great depth, and infinite variety [which will] become the actual spiritual guide and structuring force of [our] civilization." 32 That this revelation will come from literature, secular philosophy and the arts, Campbell reiterates - along with the implications that this fact has for the modern change in consciousness - in The Inner Reaches of Outer Space, the last book completed before his death. Having defined mythology, ancient and modern, as metaphorical of the psychological posture of a civilization, and located it within "the sociological structure coordinate to such a posture [called] a cultural monad," Campbell claims that the role of these monads is to invest culture with spiritual sense. 33 The modern predicament, however, is one of vacuum: "there are no more intact monadic horizons." Their dissolution suggests that "a fundamental transformation of the historical conditions of [the world] and its inhabiting humanity is in prospect." 34 For Campbell, this entails a pressing need for "constructing" a new mythology - one "which is rapidly becoming a social as well as spiritual necessity," and which will rest on a foundation of four major characteristics. 35 It will be of the whole human race, will be relevant to our present knowledge, is already implicit among men as knowledge $a$ priori, native to the mind, and will be realized in and through art.

\section{The Rise of Mythopoeic Fantasy}

Whether Campbell was aware of it or not, the process of constructing new mythology in and through literature was well advanced by 1980 . It was happening in fantasy, the rise of which is one of the most spectacular literary development of the twentieth century. Given the number of novels written and the amount of serious academic criticism that has accompanied them, the process invokes explicit comparisons with the rehabilitation of myth that was happening simultaneously. This synchronicity, I

31. Joseph Campbell, The Masks of God: Creative Mythology (New York: Penguin, 1991), p. 5 .

32. Campbell, Masks, pp. 3-4.

33. Campbell, The Inner Reaches, p. xiv.

34. Campbell, The Inner Reaches, p. xix.

35. Campbell, The Inner Reaches, p. xxii. 
think, is mostly due the fact that fantasy - as a cognitive strategy which presupposes the existence of the supernatural and an artistic mode in narrative fiction - demands from its readers a kind of mythical openness and thus can be seen as a backlash of the rationalist and reductionist stifling of mythos in favour of logos. In literature, the core of fantasy is the genre of mythopoeic fantasy: a narrative constructed from artistically re-imagined mythic materials and archetypes aimed to create an imaginative experience of a universe in which metaphysical concepts are objective realities. In this world the supernatural not only exists objectively but also places moral and ethical demands on the protagonists. As a result, their actions and the development of the plot are meant to show why and how moral choices and qualities matter; why and how they make us truly human. It is with this understanding of the major impulse behind fantasy that in her 1992 Twentieth-Century Fantasists Kath Filmer asserts: "[t]wentieth-century fantasy writers have often been in the vanguard of the movements which now characterize the conscience of the western world [and displayed] vision and courage ... in raising, through a popular medium, issues of both cultural and global significance."36 This is also why Patricia Karen Smith in her 1993 The Fabulous Realm: A Literary Historical Approach to British Fantasy thinks it most appropriate to designate the post 1950s stage of the evolution of fantasy by the name "dynamic," 37 and sees it as "characterized by a complex, fast-moving, and energetic approach" informed by "the mythic priorities" and by "the key premise [of] belief and its prevailing strength.” 38

It is not insignificant that the emergence of mythopoeic fantasy, primarily in the writings of J. R. R. Tolkien and C. S. Lewis in the late 1940s and 1950s, coincided with the emergence of powerful reinterpretations of myth in the writings of Jung, Eliade, Frye, and Campbell. Although it would be misleading to claim that Lewis and Tolkien were absolutely unique in the tradition of fantasy literature, it is useful to single them out not only because, as authors, they elevated fantasy to academic respectability and created the genre of mythopoeic fantasy, but also because, as critics, they explored its value, techniques, mechanisms and appeal. Perhaps the deepest link between Lewis and Tolkien and the four myth theorists is their shared belief that the imaginative and spiritual impoverishment characteristic of much of contemporary life may be countered by soul-nourishing stories composed in the "poetics of

36. Kath Filmer ed., Twentieth-Century Fantasists: Essays on Culture, Society and Belief in Twentieth-Century Mythopoeic Literature (St. Martin's Press: New York, 1992), p. 3.

37. Patricia Karen Smith, The Fabulous Realm: A Literary Historical Approach to British Fantasy (Methuen, N. J. and London: The Scarecrow Press, 1993), p. 3.

38. Smith, pp. 310-311. 
myth" - that is with conscious use of re-imagined mythic materials such as archetypes, plot structures, characters, events, motifs, and so on, derived from both ancient mythologies and from myths cherished by contemporary culture. Tolkien explicitly linked these specific stories with the "mythical or total (unanalysable) effect" and demonstrated that they educate the soul on four levels which he called Fantasy, Recovery, Escape, and Consolation. 39 Lewis asserted that mythopoeic narratives draw from the world of the spirit, convey "certain profound experiences which are ... not [transmissible] in any other form,"40 and may be seen as recreations of Jungian archetypes. ${ }^{41}$ These, and many other of their claims about the specific kind of literature they produced and defended resonate well not only with Jung's, Eliade's, Frye's and Campbell's theorizing about myth, but also with the statements of numerous mythopoeic authors such as, among others, Ursula Le Guin, Lloyd Alexander, Orson Scott Card, Madeleine L'Engle, Peter Beagle and Susan Cooper. In this way, Lewis and Tolkien must be credited with having proposed a template of fiction which integrates mythos and logos as complementary ways of realizing and expressing the full human potential, while refining the mind and educating the "feeling intellect" of its readers in the language of symbols and archetypes.

In what way this type of fiction can be seen as an exploration of the components of the new mythology that Campbell posited I have endeavoured to demonstrate in my book One Earth, One People..$^{2}$ Perhaps the most important conclusion I was able to arrive at in my study was a perception that although each mythopoeic author is unique and presents a vision of the secondary world unlike others, they all share certain universals, such as deep structures, interpretative paradigms and values that run through them. Before I suggest what common thematic elements identified by Campbell as components of a new mythology in the making can be traced in specific fantasy novels, an important proviso must be made. Whereas I am positive that these novels may be said to participate in the search for a new mythology as Campbell imagined it, I must stress that that no specific fantasy novel, a genre, or a group of novels can be taken as a formulation of new mythology. Given that no novel or

39. J. R. R. Tolkien, "On Fairy Stories" in Tree and Leaf, ed. Christopher Tolkien (London: Grafton, 1992), 9-74, p. 32.

40. C. S. Lewis, "On Stories" in On Stories and Other Essays on Literature, ed. Walter Hooper (New York: Harvest/HBJ Publishers, 1982), 3-20, p. 15.

41. Lewis, p. 3.

42. Marek Oziewicz, One Earth, One People: The Mythopoeic Fantasy Series of Ursula K. Le Guin, Lloyd Alexander, Madeleine L'Engle and Orson Scott Card (Jefferson: McFarland, 2008). 
group of novels in the modern world is able to carry the same social, spiritual and existential importance as was attached to the old mythologies for centuries, a new mythology for unified humanity that Campbell spoke about may issue from a cumulative effect of dominant patterns of thinking and feeling evident in art and other areas of human activity rather than from a specific, single "revelation" - narrative or otherwise.

Campbell's conviction that the new story will embrace, respect and treat equally the people of all religions, all racial backgrounds, and of both genders is being realized in mythopoeic fantasies which stress that only through cooperation instead of separatism, through mutual respect instead of mere tolerance, and through partnership instead of domination we can secure peace and happiness for our multicultural, multi-religious and bi-gendered planet. Good examples of such narratives are Ursula Le Guin's The Earthsea Sequence and Orson Scott Card's The Tales of Alvin Maker. The former is a mythopoesis on the Taoist notion of harmony and complementarity of opposites, with the plot woven around overcoming the divisions and prejudices which separate men from women, white Kargs from brown Hardic people, humans from dragons; the latter - a mythopoesis on the myth of America as a Promised Land and a Land of Freedom for All - deals with an imagined possibility of a peaceful coexistence of white, black, and red peoples in an alternative, $19^{\text {th }}$ century United States.

Another aspect of the new mythology implied in Campbell's claim about its universal applicability and future-oriented potential, is the recognition of the fact that building the future entails integrating the past. In other words, the new story of unified humanity will need to incorporate the valid elements of cultural and religious traditions which for centuries guided different human civilizations and are still a strong presence in many people's minds. This integration reflects Campbell's conviction that, while none of the present cultural monads available to humanity is fully relevant to the modern situation, many of their insights and elements are. These will be included in the new story, providing a sense of continuity and evolution between the old and new paradigms. Mythopoeic fantasies which explore and explicitly reflect this desire for the integration of the past and the future are, among others, Lloyd Alexander's The Chronicles of Prydain and Susan Cooper's The Dark is Rising Series. Both series are mythopoeic recreations of Welsh myth; although Alexander's narrative is set in an imaginary $10^{\text {th }}$ century and Cooper's in the 1960 s, both series are a type of myth-telling in which relationships between the past, the present, and the future are encoded. As Cooper and Alexander suggest, our personal and collective 
past is irretrievable and retrievable, gone yet always present, not only in the universe of our memory but also in the universe of our hopes and aspirations.

Campbell's assertion about the new story of humanity as compatible with the discoveries of modern science applies to mythopoeic fantasy as well. If the new mythology of our soon-to-be-unified planet should continue to nourish a sense of actual participation in a realization of transcendence, infinity, and abundance - this, in Campbell's opinion, being "the first and most essential service of a mythology" - it can do so only by incorporating the insights of holistic sciences. 43 As mythologies of old, it will serve an important cosmological function of relating human species to the awesome spectacle of the universe, but will transcend the nineteenth-century, longobsolete dichotomy of science versus religion by redefining our conceptions of universe, of transcendence, and of the human being in a way that will be in keeping with the discoveries of modern sciences such as physics, biology, neurobiology, developmental psychology, ecology and many others. Perhaps the best example of this type of mythopoeia to date is Madeleine L'Engle's Time Quartet. A mythopoesis on the Christian myth, the series is an extended imaginative experiment about how specific claims of modern holistic sciences may be used to articulate Christian and spiritual truths in the language of contemporary culture, a culture that is very much science oriented.

The fourth major element of the new mythology Campbell spoke about is that the new story will reawaken us to the sacredness and preciousness of the natural world, and thus re-enchant it for us. The cosmological scope of the new mythology will be matched by its simultaneous stress on the ordinary, on what we have so far taken for granted and abused so much. If Campbell says that in the new story the natural world will be resacralized, mythopoeic fantasy it a perfect realization of ecological and holistic narrative that he has in mind. Indeed, since mythopoeic fantasies negotiate between the human and the nonhuman, often questioning the anthropocentric attitudes; since they assert that human culture affects the physical world and is affected by it; since they frequently manifest "the troubling awareness that we have reached the age of environmental limits, a time when the consequences of human actions are damaging the planet's basic life support systems"; 44 and since they stress the ethical, environmental, cultural and political implications of human actions, they

43. Campbell, The Inner Reaches, p. xx.

44. Cheryll Glotfelty, "Introduction. Literary Studies in an Age of Environmental Crisis," in The Ecocriticism Reader, eds. Cheryll Glotfelty and Harold Bloom (Athens and London: The University of Georgia Press, 1996), xv-xxxvii, p. xx. 
may be seen as especially congenial to the exploration of our relationships with nature. Joseph Bruchac's Dawn Land Series, Orson Scott Card's The Tales of Alvin Maker or Ursula Le Guin's The Earthsea Sequence are just three of the many examples which could be used to substantiate this point. While Bruchac recreates the Great Lakes region and the world Native Americans from around 800o B.C., Card does so with all of North America of the alternative 19th century, and Le Guin does so with an imagined, medieval-looking cultures of the world of the Earthsea, each author stresses the importance of environmental balance and associates ethically sound behaviour with thoughtful and responsible attitude to the natural world.

Although the above elements do not exhaust the list of characteristics which make it possible to see works of mythopoeic fantasy as part of imaginative speculation on the components of the new mythology, they are sufficient to suggest the viability of this perspective. Two other things may be added here. The first is Lewis's and Tolkien's insistence that in order to express the truths of the inner world mythopoeic fantasy must employ the regenerative powers of myth and mythmaking; the imperative which clearly situates the genre in the mainstream of the twentiethcentury revaluation of myth. The second is that its mythopoeic component opened the genre to a seminal interaction with the discoveries of holistic sciences. Fantasy and science fiction - here the demarcation line may be blurred at times - are probably the two categories most responsive to such modern and often subversive hypotheses as the theory of relativity, multidimensionality of existence, Rupert Sheldrake's theory of morphic resonance, James Hillman's archetypal theory, Richard Dawkins' theory of memetics, Ken Wilber's spectrum of consciousness, James Lovelock's Gaia theory and many others. This, of course, is not evidenced as much in Tolkien's and Lewis's mythopoeic fantasy as in that of later authors, especially that since the early seventies, which saw the incipient awareness of a global change of consciousness 45 , the recognition of the crisis and the hope for renewal drawn from mythic stories were in the air. The decades which saw the proliferation of fantasy - from 1960s through 1990 s coincided with the appearance of books such as Thomas Kuhn's The Structure of

45. See, for example, Chad Walsh's argument in his 1974 "Charles Williams's Novels and the Contemporary Mutation of Consciousness" (in Myth, Allegory and Gospel: An Interpretation of J. R. R. Tolkien, C. S. Lewis, G. K. Chesterton, and Ch. Williams, ed. John Warwick Montgomery [Minneapolis: Bethany Fellowship, 1974], 53-77). Here, Walsh claims that "a genuine change of consciousness is taking place before our bewildered eyes" and that certain works of literature represent "visible byproducts of that change" (59). Walsh calls this fundamental transformation of the way life was felt a "historical rarity" (60) and ascribes to it seven characteristic elements (59-62), all of which are actualized in mythopoeic fantasy. 
Scientific Revolutions (1961), Ken Wilber's The Spectrum of Consciousness (1975), or Fritjof Capra's The Tao of Physics (1977). All of them suggested that our culture and science witness the reshaping of the old, local paradigms toward a universal one, more suited to the needs of the modern, increasingly unified world.

How perceptive Tolkien and Lewis were in their assessment of the liberating potential of mythopoeia can be glimpsed from the proliferation of fantasy literature and movies, from the growing popularity of Role Playing Games, and from the plethora of scholarly publications of the last four decades, many of which expand certain claims made by Tolkien and Lewis. Increasingly, the focus is on the regenerative powers of myth and mythmaking as is the case, for example, in Jane Yolen's 2000 Touch Magic. In this brilliant book the American mythopoeist, children's literature author and critic explores four major functions of mythic narratives in the intellectual development of the child. Asserting that these stories provide (1) a landscape of allusion, (2) a knowledge of ancestral cultures, (3) a tool in moulding "a mentally stable individual," 46 and (4) "a framework or model for an individual's belief system," Yolen calls "an understanding of, a grounding in, a familiarity with the old lores and wisdoms of the so-called dead worlds ... a basic developmental need." 47 Like other mythopoeic fantasists she knows that "stories lean on stories, cultures on cultures." 48 She is also convinced that "we remake our mythology in every age out of our own needs." 49 In this perspective mythopoeia - the artistic recreation of older, mythic elements which are then woven into new stories - and familiarity with mythopoeic stories is a vital part of every child's education, without which the child "lacks true memory and thus lacks the ability to learn," nor can they "generalize or interpret [their] experience." ${ }_{50}$ Yolen asserts that "if we deny our children their cultural, historical heritage, their birthright in the stories" the result will be that

instead of creating men and women who have a grasp of literary allusion and symbolic language, and a metaphorical tool for dealing with the serious problems of life, we will be forming stunted boys and girls who speak only a barren language, a language that accurately reflects their equally barren minds. ${ }^{1}$

46. Jane Yolen, Touch Magic. Fantasy, Faerie and Folklore in the Literature of Childhood (Little Rock: August House Publishers, 2000), p. 17.

47. Yolen, p. 14.

48. Yolen, p. 15 .

49. Yolen, p. 16.

50. Yolen, p. 18.

51. Yolen, p. 18. 
JOSEPH CAMPBELL'S "NEW MYTHOLOGY"

\section{Conclusion}

A glance at any among a large number of recently published books on moral education, character education, and literary education $5^{2}$ leaves no doubt that arguments such as those advanced by Yolen are almost universally accepted. Also, a continuing appreciation of, on the one hand, Jung, Eliade, Campbell, Frye along with other serious theorists of myth, and of Lewis, Tolkien, Le Guin and other mythopoeic fantasists on the other suggests that theories of myth as somewhat reflecting the psychic unity of humankind have remained as appealing as mythic narratives, old and new. Whereas it remains to be seen whether western civilization is, as I would tend to agree, taking a holistic turn, it is quite clear that in many areas - politics, economy, ecology, culture - the planet rather than a state is seen as a point of reference. A new, polyphonic cosmopolitanism is being born in the circulation of what Benita Parry calls "the 'global flows' of transnational cultural traffic." 53 Part of the process is the recognition of fantasy and science fiction as legitimate subjects for academic study. Another is a trend to accept the value of myth as - in Ursula Le Guin's definition - "a nonintellectual mode of apprehension" capable of connecting the conscious and unconscious realms and thus crucial for the healthy, non-alienating development of human societies and individual human beings alike. 54 In this process, the role of such popular literary genres as mythopoeic fantasy should not be underestimated.

Works of mythopoeic fantasy uphold belief in transcendence and in its intimate relation to human life. They sustain the belief in the ultimate conquest of death

52. See, for example, Colin McGinn, Moral Literacy: How to Do the Right Thing (Indianapolis: Hackett Publishing Company, 1992), Vigen Guroian, Tending the Heart of Virtue: How Classic Stories Awaken a Child's Moral Imagination (New York: Oxford UP, 1998), Paul S. Fiddes ed., The Novel, Spirituality and Modern Culture (Cardiff: University of Wales Press, 2000), Hanan Alexander, Reclaiming Goodness: Education and the Spiritual Quest (Notre Dame, IN: U of Notre Dame P, 2001), William Damon, Bringing in a New Era in Character Education (Stanford, CA: Hoover Institution Press, 2002), Stephen Prickett and Patricia Erskine-Hill ed., Education! Education! Education! Managerial Ethics and the Law of Unintended Consequences (Thorverton and Charlottesville: Imprint Academic, 2002), and Guroian, Rallying the Really Human Things: The Moral Imagination in Politics, Literature, and Everyday Life (Wilmington: ISI Books, 2005).

53. Quoted in Bruce Robbins, "Actually Existing Cosmopolitanism,” in Pheng Cheah and Bruce Robbins eds., Cosmopolitics: Thinking and Feeling Beyond the Nation (Minneapolis: U of Minnesota P, 1998): 1-19, p. 1.

54. Ursula Le Guin, "Myth and Archetype in Science Fiction," in Susan Wood ed., The Language of the Night, (New York: G. P. Putnam's Sons, 1979), 68-77, p. 70. 
based on the conviction about the essential oneness and continuity of life; they affirm individualism and the value of life based on ideals; and they evince practical concern with the good of the holistically conceived universe on all levels: personal and communal, local and global, spiritual and material. In these and other ways, the genre thus plays an important role in shaping modern readers' response to contemporary challenges, influences other genres of fantasy fiction and explores the components of a new story, or new mythology, for all humankind. It does so by creating in their readers a state of mind in which fantasy "fiction" becomes a "true narration" about the possibility of achieving harmony on earth and illuminates the real world by prefiguring possible human actions and institutions. 